\title{
Green Isolation and Characterization of Marine Actinomycetes in Tharangambadi Coastal Area in Nagapattinam District, Tamil Nadu
}

\author{
Ramarajan $\mathrm{K}^{1}$, Senthilkumar $\mathrm{PK}^{1^{\star}}$ and Ramakrishnan $\mathbf{N}^{2}$ \\ ${ }^{1}$ Department of Microbiology, Annamalai University, Tamil Nadu, India \\ ${ }^{2}$ Department of Phytochemistry, Tamil Nadu Veterinary University Training and Research Centre, Thanjavur, Tamil Nadu, India
}

*Corresponding author: P.K.Senthilkumar, Assistant professor and Head, Department of Microbiology, Faculty of Sciences, Annamalai University,60/South Street, New Mathur, Pasupathi Kovil, Tamil Nadu, India, Tel: +91860894311; E-mail: drpks1980@gmail.com

Received date: July 19, 2017; Accepted date: August 08, 2017; Published date: August 9, 2017

Copyright: (c) 2017 Ramarajan K, et al. This is an open-access article distributed under the terms of the Creative Commons Attribution License, which permits unrestricted use, distribution, and reproduction in any medium, provided the original author and source are credited.

\begin{abstract}
As a result of the continuous evolution of microbial pathogens towards antibiotic-resistance, therefore development of new and effective antimicrobial compounds. Source of novel antimicrobial metabolites. Further, the antimicrobial metabolites were extracted from the isolate using ethyl acetate solvents and the antimicrobial efficacies were screened by chemical analysis and tested against bacterial pathogens. The metabolites of isolate showed maximum zone of inhibition against all the pathogens viz., Pseudomonas aeruginosa, Escherichia coli, Klebsilla pneumoniae, Bacillus cereus and Staphylococcus aureus as $21 \pm 0.12,20 \pm 0.42,21 \pm 1.2,16 \pm 2.01,15 \pm 0.47$ respectively. The marine samples which displayed antibacterial activity of actinomycetes may be useful in the clinical conditions where higher secondary metabolites against antibiotic resistant bacteria.
\end{abstract}

$\begin{array}{lrrrr}\text { Keywords: } & \text { Marine } & \text { actinomycetes; } & \text { Chemical } & \text { screening; } \\ \text { Antimicrobial } & \text { activity; } & \text { Cross-streak } & \text { method; } & \text { Molecular }\end{array}$ characterization

\section{Introduction}

Microorganism can become resistant to antibiotics and chemotherapeutic agents by various mechanisms (via- $\beta$-lactamase) or modification by altering targets or preventing the access of drugs to the target [1]. Therefore, action must be taken to reduce these problems by controlling the use of antibiotics [2]. Microbial natural products have been one of the major resources for discovery of novel drugs. Among the potential sources of natural products, bacteria have been proven to be a prolific source with a surprisingly small group of taxa accounting for the vast majority of compounds discovered. Of the 22,000 known microbial secondary metabolites, $70 \%$ are produced by actinomycetes, and two thirds of them are contributed by the genus Streptomyces [3]. These metabolites are known to possess, antibacterial, antifungal and anti-inflammatory activities [4]. A marine microorganism has produced novel metabolites [5]. The production of various natural compound and their specialized mechanisms for adaptation to extreme environment [6]. Bacteria are normal biota of the marine ecosystems and are found in various environmental niches such as marine sediments, open oceans and other marine surfaces including marine living organisms [7-9]. Recently, the rate of discovery of new compounds from terrestrial actinomycetes has decreased, whereas the rate of re-isolation of known compounds from marine region has increased. It is crucial that new groups of actinomycetes from unexplored habitats be pursued as sources of novel bioactive secondary metabolites. In the present study, as it is essential to find out bioactive compounds from natural products to benefit the human being, the present study was undertaken to isolate the antimicrobial compound from the actinomycetes.

\section{Material and Methods}

\section{Sample collection}

The marine sea shore soil samples were collected from the spot a town in the Nagapattinam district of the Indian state of Tamil Nadu. It lies $15 \mathrm{~km}(9.3 \mathrm{mi})$ north of Karaikal, near the mouth of a distributary of the Kaveri River at the depth of 3.94 in, 65.62 feet near the sea side in Nagapattinam District at Tharangambadi. East Coastal region of Tamil Nadu lies between $10.10^{\circ}$ and $11.20^{\circ}$ North latitudes and $79.15^{\circ}$ and $79.50^{\circ}$ East longitudes. The sea shore soil sample has been collected from the above-mentioned locations such as Kuttiyandiyur, Manikkapangu, Sandrapadi, D Bangalo Beach and Danish Beach. The soil sample was collected at random in sterile polythene bags and stored in a refrigerator for further use [10].

\section{Isolation of actinomycetes}

Starch casein agar medium was prepared and sterilized at $249.80^{\circ} \mathrm{F}$ in $6.80 \mathrm{~kg}$ pressure for $15 \mathrm{~min}$. Then it was supplemented with Amphotericin B $50 \mu \mathrm{g} \mathrm{dm}^{-1}$ and Tetracyclin $20 \mu \mathrm{g} \mathrm{dm}^{-1}$ to prevent the bacterial and fungal growth. The medium was poured into the sterile Petri plates. $1 \mathrm{~g}$ of marine sea shore soil sample was suspended in $9 \mathrm{ml}$ of sterile double distilled water. Then the samples were serially diluted for up to $10^{-6}$ and 0.1 of the diluted samples from $10^{-2}$ was spread over the agar plates in triplites. The inoculated plates were incubated at $28 \pm$ $35.60^{\circ} \mathrm{F}$ for seven to ten days. After incubation, the Actinomycetes were observed, purified using subculture method and maintained in starch casein agar medium for further investigation. For actinomycetes culture, Czapek's broth, Bennett's broth, Starch casein broth, Yeast malt extract broth (ISP-2), Oat meal broth (ISP-3), Inorganic salt starch broth (ISP-4), Glycerol asparagine broth (ISP-5) and nutrient broth were used. 
Citation: Ramarajan K, Senthilkumar PK, Ramakrishnan N (2017) Green Isolation and Characterization of Marine Actinomycetes in Tharangambadi Coastal Area in Nagapattinam District, Tamil Nadu. J Antimicrob Agents 3: 147. doi:10.4172/2472-1212.1000147

Page 2 of 6

\section{Identification of Actinomycetes}

For phylogenetic analysis, the extraction of genomic DNA, PCR amplification of the $16 \mathrm{~S}$ rDNA and sequencing of the purified PCR production were carried out as described previously [11]. The 16S rDNA gene sequence was compared with sequences in the GenBank database using Blast. Multiple alignments were carried out with the ClustalX programme and phylogenetic analysis was conducted with the NJ plot programme.

\section{Cultural characteristics of Actinomycetes isolate}

Morphological characters and colour determination of selected isolate was studied on different media such as Yeast malt extract agar(ISP-2), Oat meal agar (ISP-3), Starch casein agar, Inorganic salts starch agar medium (ISP-4), Kennight agar, Actinomycetes isolation agar, Glycerol aspargine agar medium (ISP-5) [12] in accordance with the International Streptomycetes Project (ISP) [13]. Colour was determined using the color names lists [14].

\section{Primary screening}

Antimicrobial producing of the actinomycetes was screened by cross streak

method [15]. In this single streak of the actinomycetes was made on the surface of the modified Bennett's agar medium and incubated at 28 $\pm 2^{\circ} \mathrm{C}$. After observing a good ribbon like growth of the actinomycetes on the Petri plates, the pathogens (Escherichia coli, Bacillus cereus, Pseudomonas aeruginosa, Staphylococcus aureus and Klebsilla pneumoniae) were streaked at right angles to the original streak of actinomycetes and incubated at $98.60^{\circ} \mathrm{F}$. The antagonistic actinomycetes were isolated after 24 and $48 \mathrm{hrs}$. Based on the presence and absence of inhibition zone, the antimicrobial producing actinomycetes were selected.

\section{Extraction of secondary metabolites}

The selected antagonistic actinomycete isolates were inoculated into actinomycete isolation broth separately and incubated at $86.00^{\circ} \mathrm{F}$ in a shaker at (200-250 rpm) for seven days. After incubation, the broths were filtered through Whatman No. 1 filter paper. Then the filtrates were centrifuged separately at $5000 \mathrm{rpm}$ for $10 \mathrm{~min}$ to extract the antimicrobial compounds. The supernatant was transferred aseptically into a screw capped bottles and stored at $39.20^{\circ} \mathrm{F}$ for further assay [16].

\section{Secondary screening}

The Antibacterial activities of cell free cultures were evaluated by agar well diffusion technique. Pathogenic bacterial strains following (Escherichia coli, Bacillus cereus, Pseudomonas aeruginosa, Staphylococcus aureus and Klebsilla pneumoniae) were used. The pathogens were inoculated in Nutrient broth and kept overnight at $37^{\circ} \mathrm{C}$ for exponential growth of culture. Future, the bacterial cultures were swabbed of freshly prepared Mueller-Hinton agar plates and well created of 0.2362 in the plate. The isolated actinomycetes of cell free culture supernatants were loaded from $50 \mu \mathrm{l}$ to $100 \mu \mathrm{l}$ respectively. Then the plates were incubated at $37^{\circ} \mathrm{C}$ for $24 \mathrm{~h}$ and then zone of inhibition was measured by Antibiotic zone scale Himedia, India.

\section{Bioactive Chemical Screening}

Chemical tests were carried out on the ethyl acetate extract using procedures to identify described $[17,18]$.
Test for Carbohydrates: $2 \mathrm{ml}$ of extract, $1 \mathrm{ml}$ of Molisch's reagent and few drops of concentrated sulphuric acid were added. Purple color formation indicated the presence of carbohydrates.

Test for Flavonoids: $5 \mathrm{~cm}^{-3}$ of dilute ammonia solution was added to a portion of the aqueous filtrate of extract followed by addition of concentrated sulphuric acid. Appearance of yellow coloration indicated the presence of flavonoids.

Test for Alkaloids: $2 \mathrm{~cm}^{-3}$ of extract, $2 \mathrm{~cm}^{-3}$ of concentrated hydrochloric acid was added. Then few drops of Mayer's reagent were added. Presence of green color indicated the presence of alkaloids.

Test for Glycosides: $2 \mathrm{~cm}^{-3}$ of extract, $3 \mathrm{~cm}^{-3}$ of chloroform and $10 \%$ ammonia solution was added. Pink color formation indicated the presence of glycosides.

Test for Phenols: $1 \mathrm{ml}$ of the extract, $2 \mathrm{~cm}^{-3}$ of distilled water followed by few drops of $10 \%$ ferric chloride was added. Formation of green color indicated the presence of phenols.

Test for Tannins: $1 \mathrm{~cm}^{-3}$ of extract, $2 \mathrm{~cm}^{-3}$ of $5 \%$ ferric chloride was added. Formation of greenish black color indicated the presence of tannins.

Test for Saponins: $2 \mathrm{~cm}^{-3}$ of extract, $2 \mathrm{~cm}^{-3}$ of distilled water was added and shaken in a graduated cylinder for 15 min lengthwise. Formation of $1 \mathrm{~cm}$ layer of foam indicated the presence of saponins.

\section{Results}

\section{Selection of soil samples}

Soil sample were collected from site in Tamil Nadu of Nagapattinam district at Tharangambadi that represented different ecological habitats. Soil samples were taken at the depths of 0.20 in to 3.94 in below the surface which is rich in organic matter.

Various physico and chemical parameters were used for the selective isolation of actinomycetes from the collected samples.

\begin{tabular}{|l|l|l|}
\hline S. No. & Physico-chemical parameters & Values (Mean \pm SD) \\
\hline 1 & $\mathrm{pH}$ & $8.3 \pm 1.02$ \\
\hline 2 & Soil texture & Blackish in colour \\
\hline 3 & Electrical Conductivity $\left(\mathrm{dsm}-{ }^{1}\right)$ & $6.6 \pm 1.05$ \\
\hline 4 & Salinity $(\mathrm{ppm})$ & $6.2 \pm 0.49$ \\
\hline 5 & Turbidity & $3.2 \pm 2.80$ \\
\hline 6 & TDS mg dm-3 & $3.9 \pm 1.36$ \\
\hline 7 & DO mg dm-3 & $1.5 \pm 0.12$ \\
\hline 8 & Available phosphorus & $5.3 \pm 0.41$ \\
\hline 9 & Nitrogen (mg/kg ) & $1.7 \pm 1.02$ \\
\hline 10 & Potassium (mg/kg) & $53 \pm 1.05$ \\
\hline 11 & Organic carbon (mg/kg) & $213 \pm 0.16$ \\
\hline
\end{tabular}

Table 1: Physico-chemical analysis of selected soil sample from Harngambad L. Value represents Mean \pm SD; $n=3,10^{-6}$ : (Parts per Million), BDL: Below the detectable level, DO: Dissolved oxygen, TDS: Total dissolved solids. 
Citation: Ramarajan K, Senthilkumar PK, Ramakrishnan N (2017) Green Isolation and Characterization of Marine Actinomycetes in Tharangambadi Coastal Area in Nagapattinam District, Tamil Nadu. J Antimicrob Agents 3: 147. doi:10.4172/2472-1212.1000147

Page 3 of 6

Table 1 showed that physico-chemical properties of the selected soil for various essential elements and physical properties which are indispensable for vital growth of the Actinomycetes.

\begin{tabular}{|l|l|l|l|l|}
\hline S.No. & Area names & Spot & $\begin{array}{l}\text { Types of } \\
\text { sample }\end{array}$ & Number of isolates \\
\hline 1 & Kuttiyandiyur & $\begin{array}{l}\text { Sea } \\
\text { Shore }\end{array}$ & Soil sample & A1, A2, A3 \\
\hline 2 & Manikkapangu & $\begin{array}{l}\text { Sea } \\
\text { shore }\end{array}$ & Soil sample & B1, B2 \\
\hline 3 & Sandrapad & $\begin{array}{l}\text { Sea } \\
\text { shore }\end{array}$ & Soil sample & C1, C2, C3 \\
\hline 4 & Danish Beachand & $\begin{array}{l}\text { Sea } \\
\text { shore }\end{array}$ & Soil sample & D1 \\
\hline 5 & D Bagalo Beach & $\begin{array}{l}\text { Sea } \\
\text { shore }\end{array}$ & Soil sample & E1, E2, E3, \\
\hline
\end{tabular}

Table 2: Isolation of Actinomycetes from marine soil sample. AKuttiyandiyur, B-Manikkapangu, C-Sandrapadi, D-Danish Beachand, E-D-Bagalo Beach.

\section{Isolation of Actinomycetes from marine soil samples}

The marine sea shore soil samples were collected at the depth of 3.94 in, 65.62 feet near the sea side in Nagapattinam District at Tharangambadi, East Coastal region of Tamil Nadu. The following areas such as Kuttiyandiyur, Manikkapangu, Sandrapadi, D Bangalo Beach and Danish Beach were selected for the isolation of actinomycetes and soils were collected and preserved. The isolated actinomycetes strains were named as according the areas as A1, A2, A3, B1, B2, C1, C2, C3, D1, E1, E2, E3. The isolated strains were stored in sterile container (Table 2).

\section{Screening for the antimicrobial activities}

The metabolites of twelve actinomycete isolates subjected to antibacterial sensitivity investigation using starch casein agar media by cross streak method. Among the twelve metabolites actinomycetes A1 exhibited maximum effect against the pathogens (Table 3 ).

In secondary screening, the metabolites produced by actinomycetes (supernatants) were tested against the pathogens by agar well method on Muller Hinton agar media. The metabolites A1 showed maximum zone of inhibition against all the pathogens viz., Pseudomonas aeruginosa, Escherichia coli, Klebsiella pneumoniae, Bacillus cereus and Staphylococcus aureus as: $21 \pm 0.12,20 \pm 0.42,21 \pm 1.2,16 \pm 2.01$, $15 \pm 0.47$ respectively (Table 4 ).

\section{Color and culture characteristics}

The isolate A1 exhibited good growth on yeast extract agar (ISP-2), was good, aerial mycelium was yellowish gray and substrate mycelium was light yellowish brown. The growth on inorganic salt starch agar medium (ISP-4) and oat meal agar (ISP-3) were very good, aerial mycelium was whitish to chalk white. The growth on starch casein agar was very good, aerial mycelium was whitish to pale sandy and also Actinomycetes isolation agar was light yellow of aerial mycelium. The growth on YM agar was moderate, substrate mycelium was white. No growth of actinomycetes isolate was detected on Glycerol asparagines agar medium (ISP-5) (Table 5).

\section{Molecular characterization of Streptomyces spp.}

The molecular characteristics of Streptomyces sp. were evaluated by PCR amplification of 16S rRNA gene. The genomic DNA and amplified products were separated in agarose gel. The 16S rRNA genes of actinomycetes isolated from the marine seashore region were partially sequenced using specific $16 \mathrm{~S}$ rRNA sequence primer (27F-5'AGAG TTTG ATCM TGGC TCAG-3' and 149-2R-5'-GGTT ACCT TGTT ACGA CTT-3'). The sequence of actinomycetes $16 \mathrm{~S}$ rRNA were processed and deposited in Gene bank (NCBI) with the following accession number of KY000096 and strain named as Streptomyces Streptomyces rimosus- (A1). The sequence comparisons of marine Streptomyces with other sequences available in the EMBL database were studied. The phylogenetic analysis (neighbour joining tree) revealed that 1404 bop sequence of the seashore isolates Streptomyces $s p$. were similar to that of the exiting species of Streptomyces rimosus (Figure 1).

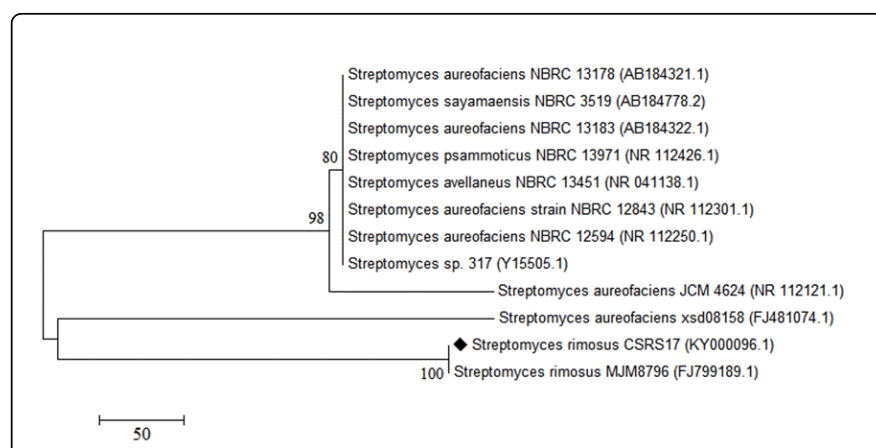

Figure 1: Neighbor joining phylogenetic tree (1) was constructed for the potential strain Streptomyces rimosus with their closest NCBI (BLASTn) strains based on the 16S rRNA gene sequences. This analysis was done based on Maximum-likelihood method using MEGA 7. Numbers at nodes indicate levels of bootstrap support (\%) and the black dot indicates the potential strain of this study.

\section{Secondary metabolites screening of ethyl acetate extract- Streptomyces rimosus (A1)}

The Streptomyces rimosus-A1 produced different secondary metabolites such as carbohydrate, Flavanoids, Alkaloids, Glycosides and Phenols. After involved in phytochemical reagents such as Molash reagent, Ferric chloride, sodium hydroxide etc. as summarized in Table 6.

\section{Discussion}

In the present study, totally twelve strains of actinomycetes were isolated from marine soil in Tharangambadi, East Coast region Nagapattinam District in Tamil Nadu. The first report on marine actinomycetes was made by Corke and Chase [19] from salt muds. Terrestrial soils have hitherto been the predominant and widely exploited source and investigations on marine Streptomyces are few and inconclusive. The soil from which the actinomycetes were isolated results in the parameter susceptible to the environment of optimum status for the growth of the actinomycetes. Soil samples were taken from a depth of $0-5 \mathrm{~cm}$ of top layer. It has been known that top soil is rich in organic matter and microbes where most of the biological activities occur. The population of actinomycetes decreased 
Citation: Ramarajan K, Senthilkumar PK, Ramakrishnan N (2017) Green Isolation and Characterization of Marine Actinomycetes in Tharangambadi Coastal Area in Nagapattinam District, Tamil Nadu. J Antimicrob Agents 3: 147. doi:10.4172/2472-1212.1000147

Page 4 of 6

significantly with soil depth as there is decrease in organic substrate as well as aeration is poor in deeper layers of soils $[19,20]$.

\begin{tabular}{|c|c|c|c|c|c|c|}
\hline \multirow{2}{*}{ S.No. } & \multirow{2}{*}{ Isolates } & \multicolumn{5}{|l|}{ Zone of inhibition $(\mathrm{mm})$} \\
\hline & & Pseudomonas aeruginosa & Escherichia coli & Klebsilla pneumoniae & Bacillus cereus & Staphylococcus aureus \\
\hline 1 & A1 & ++ & ++ & ++ & ++ & ++ \\
\hline 2 & A2 & + & + & + & ++ & - \\
\hline 3 & A3 & - & - & + & + & - \\
\hline 4 & B1 & + & - & - & + & - \\
\hline 5 & B2 & - & - & + & - & - \\
\hline 6 & C1 & + & - & - & - & ++ \\
\hline 7 & C2 & - & - & ++ & - & - \\
\hline 8 & C3 & - & + & - & - & - \\
\hline 9 & D1 & - & - & + & - & - \\
\hline 10 & E1 & + & - & - & + & - \\
\hline 11 & E2 & - & ++ & - & - & + \\
\hline 12 & E3 & - & - & ++ & - & - \\
\hline
\end{tabular}

Table 3: Primary screening of marine actinomycetes. -: No inhibition,+: Moderate inhibition, ++: High inhibition.

\begin{tabular}{|c|c|c|c|c|c|c|}
\hline \multirow{2}{*}{ S.No. } & \multirow{2}{*}{ Isolates } & \multicolumn{5}{|c|}{ Zone of inhibition $(\mathrm{mm})$} \\
\hline & & $\begin{array}{l}\text { Pseudomonas } \\
\text { aeruginosa }\end{array}$ & Escherichia coli & Klebsilla pneumoniae & Bacillus cereus & Staphylococcus aureus \\
\hline 1 & $\mathrm{~A} 1$ & $21 \pm 0.12$ & $20 \pm 0.42$ & $21 \pm 1.2$ & $16 \pm 2.01$ & $15 \pm 0.47$ \\
\hline 2 & $\mathrm{~A} 2$ & $08 \pm 1.04$ & $10 \pm 1.04$ & $08 \pm 0.75$ & $13 \pm 1.04$ & $\mathrm{NZ}$ \\
\hline 3 & A3 & $08 \pm 1.48$ & $N Z$ & $10 \pm 1.02$ & $08 \pm 0.42$ & $\mathrm{NZ}$ \\
\hline 4 & B1 & $11 \pm 1.02$ & $N Z$ & $\mathrm{NZ}$ & $08 \pm 1.20$ & $\mathrm{NZ}$ \\
\hline 5 & B2 & $\mathrm{NZ}$ & $N Z$ & $10 \pm 1.42$ & NZ & $\mathrm{NZ}$ \\
\hline 6 & $\mathrm{C} 1$ & $08 \pm 1.22$ & $N Z$ & $\mathrm{NZ}$ & NZ & $13 \pm 1.20$ \\
\hline 7 & $\mathrm{C} 2$ & $\mathrm{NZ}$ & $N Z$ & $12 \pm 0.48$ & $\mathrm{NZ}$ & $\mathrm{NZ}$ \\
\hline 8 & C3 & $\mathrm{NZ}$ & $10 \pm 1.24$ & $\mathrm{NZ}$ & NZ & $\mathrm{NZ}$ \\
\hline 9 & D1 & $\mathrm{NZ}$ & $N Z$ & $08 \pm 1.35$ & NZ & $N Z$ \\
\hline 10 & E1 & $10 \pm 0.48$ & $N Z$ & $\mathrm{NZ}$ & $08 \pm 1.20$ & $N Z$ \\
\hline 11 & E2 & NZ & $11 \pm 1.21$ & $\mathrm{NZ}$ & NZ & $08 \pm 0.46$ \\
\hline 12 & E3 & $\mathrm{NZ}$ & $N Z$ & $12 \pm 1.32$ & $\mathrm{NZ}$ & $\mathrm{NZ}$ \\
\hline
\end{tabular}

Table 4: Secondary screening of marine Actinomycetes. Diameter of zone of inhibition including well diameter $6 \mathrm{~mm}$, Value represents mean \pm $\mathrm{SD} ; \mathrm{n}=3$, NZ: No zone of inhibition.

Activity of extracts was quantified and compared with each other as well as with standard antibiotics by two different methods including primary screening and MIC determination [21]. In this present investigation, actinomycete Al was isolated from the soil exhibited potential antibacterial activity against some pathogens in primary screening revealed that the species among the twelve isolated from different coastal area. In the secondary screening, the A1 exhibited maximum zone of inhibiton against the pathogens like Pseudomonas aeruginosa, B. cereus, $S$. aureus, E. coli and Klebsiella pneumoniae in the efficient manner. 
Citation: Ramarajan K, Senthilkumar PK, Ramakrishnan N (2017) Green Isolation and Characterization of Marine Actinomycetes in Tharangambadi Coastal Area in Nagapattinam District, Tamil Nadu. J Antimicrob Agents 3: 147. doi:10.4172/2472-1212.1000147

Page 5 of 6

\begin{tabular}{|l|l|l|l|}
\hline S.No. & Medium & Test & Properties \\
\hline 1 & Yeast malt extract agar (ISP-2) & SM,AM & Whitish, pale greyish and brown \\
\hline 2 & Oat meal agar (ISP-3) & AM & Whitish to chalk white \\
\hline 3 & Inorganic salt starch agar(ISP-4) & SM & Sandal white \\
\hline 4 & Glycerol asparagines agar(ISP-5) & AM & No growth \\
\hline 5 & Starch casein agar & AM & Whitish to pale sandy \\
\hline 6 & Actinomycetes isolation agar & AM & Light yellow \\
\hline 7 & Kennight's agar & AM & Pale yellow, brown \\
\hline
\end{tabular}

Table 5: Cultural characteristics of Actinomycetes-(A1) on different culture media ISP: International Streptomyces Project; Pigmentation: Nil for all the media; AM: Aerial Mycelium; SM: Substrate Mycelium.

\begin{tabular}{|l|l|l|}
\hline Test & Response & Result \\
\hline Carbohydrates & Purple color & + \\
\hline Flavonoids & Yellow coloration & + \\
\hline Alkaloids & Presence of green color & + \\
\hline Glycosides & Pink color & + \\
\hline Phenols & Absence of green color & + \\
\hline Tannins & Absence of block color & - \\
\hline Saponins & Absence of foam layer & - \\
\hline Amino Acids & Presence of blue color & + \\
\hline
\end{tabular}

\section{Acknowledgment}

We thank Dr. P.K. Senthilkumar, Head Department of Microbiology, Annamalai University. Carte for critically reading the manuscript, his helpful comments and his encouraging remarks.

\section{References}

1. Saier MH, Paulsen IT, Sliwinski MK, Pao SS, Skurray RA, et al. (1998) Evolutionary origins of multidrug and drug-specific efflux pumps in bacteria. FASEB J 12: 265-274.

2. Dash C, Ahmad A, Nath D, Rao M (2001) Novel bifunctional inhibitor of xylanase and aspartic protease: Implications for inhibition of fungal growth. Antimicrob Agents Chemother 45: 2008-2017.

3. Subramani R, Aalbersberg W (2012) Marine actinomycetes: An ongoing source of novel bioactive metabolites. Microbiological Research 167: 571-580.

Table 6: Screening of secondary metabolites in ethyl acetate extract Streptomyces rimosus-(A1). + means (Positive), - means (Negative)

Thus A1 was subjected to identification of strain by $16 \mathrm{~s}$ rRNA method. From the identification the evolutionary distances were computed using the maximum-composite-likelihood method and the evolutionary analyses was conducted using MEGA7 software. The tree topologies were evaluated by bootstrap analyses based on 1,000 replicates and phylogenetic trees were inferred using the neighborjoining method. 16S rRNA gene sequences of our strains exhibited sequence similarity in the range of $99-100 \%$ with those of validly described species of genus Streptomyces. High 16S rRNA gene sequence similarities are often found between members of Streptomyces [22]. Comparison of strains with their nearest relatives in terms of phenotypic and biochemical features indicated similarities and dissimilarities on the basis of literature review [23-29].

\section{Conclusion}

From the finding of the present investigation, it was confirmed the ethyl acetate extract of Streptomycetes risosmus showed a higher antimicrobial activity than the other actinomycetes. The higher activity was due to the presence of alkaloids, phenol and flovanoids, Which Exhibited significant antioxidant and antibacterial activities. Above all, it has a high inhibitory effect on the receptor of selected pathogenic bacteria; however the safety, potency and allergic studies are important before clinical trials.

4. Ravikumar S, Fredimoses M, Gnanadesigan M (2012) Anticancer property of sediment actinomycetes against MCF-7 and MDA-MB-231 cell lines. Asian Pac J Trop Biomed 2: 92-96.

5. Fenical W, Baden D, Burg M, Goyet, CV, Grimes, JD, et al. (1999) From Monsoons to Microbes: Understanding the Ocean's Rolein. Human Health Washington Human Health, National Academy Press. Washington DC, USA.

6. Solingen VP, Meijer D, Kleij WA, Branett C, Bolle R, et al. (2001) Cloning and expression of an endocellulase gene from a novel Streptomycetes isolated from an East African soda lake. Extremophiles 5: 333-341.

7. Wilson CA, Stevenson LH (1980) The dynamics of the bacterial population associated with a salt marsh. J Expt Mar Biol Ecol 48: 123-138.

8. Nair S, Simidu U (1987) Distribution and significance of heterotrophic marine bacteria with antibacterial activity. Appl Environ Microbiol 53: 2957-2962.

9. Austin B (1992) Quantification of marine microbial populations. In: Marine microbiology, Cambridge University Press pp: 31-42.

10. Exposito IL, Amigo L, Recio I (2012) A mini-review on health and nutritional aspects of cheese with a focus on bioactive peptides. Dairy Sci Technol 92: 419-438.

11. Rainey FA, Ward-Rainey N, Kroppenstedt RM, Stackebrandt E (1996) The genus Nocardiopsis represents a phylogenetically coherent taxon and a distinct actinomycete lineage: proposal of Nocardiopsiaceae fam. nov. Int J Syst Bacterial 46: 1088-1096.

12. Ratna R, Chandrika V, Kala RR, Kala R (1993) Effect of different media for isolation, growth and maintenance of actinomycetes from mangrove sediments. Indian J Mar Sci 22: 297-299.

13. Shirling EB, Gottileb D (1966) Methods for characterization of Streptomyces species. Int J Syst Bacteriol 16: 313-340. 
Citation: Ramarajan K, Senthilkumar PK, Ramakrishnan N (2017) Green Isolation and Characterization of Marine Actinomycetes in Tharangambadi Coastal Area in Nagapattinam District, Tamil Nadu. J Antimicrob Agents 3: 147. doi:10.4172/2472-1212.1000147

Page 6 of 6

14. Pridham TG, Tresner HG (1974) Streptomycetaceae: Bergey's manual of determinative bacteriology (8th Edition), Baltimore pp: 747.

15. Egorov NS (1985) Antibiotics, a scientific approach. Mir Publishers. Moscow.

16. Sambamurth K, Ellaiah P (1974) A new streptomycin producing neomycin (B and C) complex, S. marinensis (part-1). Hind Antibiot Bull 17: 24-28.

17. Harborne JB, Rai M (1973) Phytochemical methods. A guide to modern techniques of plant analysis, London.

18. Trease GE, Evans WC (1989) Pharmacology (11th Edition), London pp: 784.

19. Corke CT, Chase FE (1964) Comparative studies of Actinomycetes populations in acid podzolic and neutral mull forest soils. Soil Sci Soc Am J 28: 68-70.

20. Essien JP, Udosen ED (2000) Distribution of actinomycetes in oil contaminated ultisols of the Niger Delta (Nigeria). J Environ Sci 12: 296-302.

21. Solanki R, Lal R, Khanna M (2011) Antimicrobial activities of actinomycetes from diverse ecological habitats in Delhi and its adjoining States, India. J Microbial World 13: 233-240.

22. Guo Y, Zheng W, Rong X, Huang Y (2008) A multilocus phylogeny of the Streptomyces griseous 16S rRNA gene clade: use of multilocus sequence analysis for Streptomyces systematic. Int J Syst Evol Microbiol 58: 149-159.
23. Williams ST, Goodfellow M, Alderson G (1989) Genus Streptomyces Streptomyces. Bergey's Manual of Systematic Bacteriology 4: 2452-2492.

24. Labeda DP, Price NP, Kroppenstedt RM, Donahue JM, Williams NM, et al. (2009) Streptomyces atriruber sp. nov. and Streptomyces silaceus sp. nov., two novel species of equine origin. Int J Syst Evol Microbiol 59: 2899-2903.

25. Luo Y, Xiao J, Wang Y, Xu J, Xie S, et al. (2011) Streptomyces indicus sp. nov., an actinomycete isolated from deep-sea sediment. Int J Syst Evol Microbiol 61: 2712-2716.

26. Ningthoujam DS, Sanasam S, Nimaichand S (2011) studies on bioactive actinomycetes in a Niche Biotope, Nambul River in Manipur, India. J Microbial Biochem Technol S6: 001.

27. Reddy TV, Mahmood S, Paris L, Reddy YH, Wellington EM, et al. (2011) Streptomyces hyderabadensis sp. nov., an actinomycete isolated from soil. Int J Syst Evol Microbiol 61: 76-80.

28. Sazak A, Şahin N, Güven K, Işık K, Goodfellow M (2011) Streptomyces samsunensis sp. nov., a member of the Streptomyces violaceusniger clade isolated from the rhizosphere of Robinia pseudoacacia. Int J Syst Evol Microbiol 61: 1309-1314.

29. Khanna M, Solanki R (2012) Streptomyces antibioticalis, a novel species from a sanitary landfill soil. Indian J Microbiol 52: 605-611. 